\title{
ÉLŐNYELV
}

\section{Nyelvjárási jelenségek hatása általános iskolás tanulók írásgyakorlatára Tornalján}

1. Bevezetés. A nyelvjárásokra irányuló kutatómunkák jelentős része kizárólag a beszélt nyelvvel foglalkozik. Lényegesen kevesebb azon kutatások száma, amelyek a nyelvjárási háttér írásbeli nyelvhasználatra való hatásának vizsgálatára irányulnak. A kisebbségben élő magyarság esetében az anyanyelv elsajátítása korántsem zökkenőmentes folyamat. A szlovákiai magyar közösség kétnyelvű beszélőközösség, s az általa használt nyelvváltozatok kontaktusváltozatok (VANČONÉ 2010: 213), ugyanakkor népnyelvi eredetű regionalizmusok is színezik.

A tanulmány alapjául szolgáló kutatást a tornaljai Kazinczy Ferenc Magyar Tannyelvü Általános Iskolában végeztem. Kutatásom arra irányult, hogy feltérképezzem, milyen mértékben fordulnak elő a vizsgált diákok írásgyakorlatában nyelvjárási jelenségek, s változik-e írásbeli nyelvhasználatuk az általános iskolai képzés felső tagozatának kezdeti szakasza (ötödik osztály) és a képzést záró utolsó (kilencedik) évfolyam között.

Tornalja Szlovákiában, a Besztercebányai kerület Nagyrőcei járásában, Rimaszombattól (Rimavská Sobota) mindössze harminc kilométerre terül el. Szlovákiában az utolsó népszámlálás 2011-ben volt. Az adatok szerint Tornalja összlakosságának száma ekkor 7509 fö. A lakosság 65\%-ban magyar, 35\%-ban pedig egyéb nemzetiségü: szlovák, roma, cseh, ukrán, ruszin, lengyel, bolgár, zsidó és horvát.

A tornaljai nyelvjárás típusba sorolását illetően kijelenthetjük, hogy az $a$ fonéma illabiális $[\dot{a}]$ és az á labiális $[\bar{a}]$ realizációja folytán a palóc régióba tartozik. A palóc nyelvjárásterületen belül IMRE SAMU a régi Gömör-Kishont megye területének nyelvjárásait a középpalóc nyelvjárástípusba sorolta (IMRE 1971: 349-351). A településtől néhány kilométerre található Gice község, amely A magyar nyelvjárások atlaszában a Cssz-20. számú kutatópontként szerepel. Tornalja véleményem szerint a középpalóc és a keleti palóc nyelvjáráscsoportok között helyezkedik el: megfigyeléseim során ugyanis mindkét nyelvjárás hangtani sajátosságaival szembesültem.

2. A kutatásról. A Tornalján végzett kutatómunka három egymásra épülő fázisban zajlott 2011 és 2013 között.

2.1. Az adatközlőkről. BALOGH LAJOS meghatározása szerint az adatközlő az a személy, akit a gyüjtő különböző szempontok alapján kiválaszt, s akitől az adatokat nyeri (BALOGH 2001: 160). Jelen kutatás esetében az adatközlőket az általános iskola ötödik, hatodik és kilencedik osztályos tanulói jelentették. Az adatközlök száma összesen 84. Az ötödik osztályos tanulókra azért esett a választásom, mert KISS JENÖ megfogalmazása szerint: ,„a gyerekekben az általános iskola (felső tagozat) idején fejlődik ki a bidialektális nyelvi kompetencia, s ez egybeesik az érték- és elöítéletstruktúrák kiépülésével" (KISS 1989: 40). A kilencedik osztályos tanulók vizsgálatát azért tartottam fontosnak, mert 
ahogy azt PLETL RITA is megfogalmazta, az alapvető közmüveltség színvonalát az általános iskolai képzés alakítja ki, ezért az írásbeli közléskultúra szintjét is érdemes a képzés záró pontján mérni (PLETL 2010: 105).

2. 2. Az adatgyűjtés módszerei. A kutatás első fázisát a szakirodalom feltárása töltötte ki, ezt követően a második fázisban az összegyüjtött adatok feldolgozásával foglalkoztam. Figyelembe véve azt a tényt, hogy az adatgyüjtés hosszú és meglehetösen igényes folyamat, a vizsgálathoz szükséges tollbamondásfüzeteket már a tanév kezdetén összegyüjtöttem. A vizsgálat részét képezte az a nyelvtani gyakorlatokból összeállított feladatlap is, amelyet a diákok tanáruk jelenlétében, a magyar nyelvtan óra folyamán dolgoztak ki.

2. 3. A kérdőíves vizsgálat. A kérdőív segítségével végzett vizsgálat során alkalmazott feladatlap öt feladattípust tartalmazott, megoldásukra eredeti terveim alapján 25 percet szántam. A tanulók között szétosztott feladatlap összeállításában SÁNDOR ANNA, a Nyitrai Konstantin Filozófus Egyetem Magyar nyelv és irodalom intézetének tanára volt segítségemre. A feladatok összeállításánál azt tartottuk fö szempontnak, hogy a diákok helyesírásában leginkább nehézkesnek tünő, s leggyakrabban megjelenő hibatípusoknak megfelelő gyakorlatokat állítsunk össze. A kérdőív összeállításánál a kutatás első fázisában nyert eredményekre alapoztam. Ezek alapján tudtam, mely hibatípusok okozzák a legtöbb nehézséget, s melyekre kell különösképpen odafigyelni. A kérdések a következő hibatípusok feltérképezésére irányultak: rövid vagy hosszú mássalhangzóra utaló betühasználat, szószerkezetek kiegészítése a megfelelő ragokkal.

2.3.1. A kérdőíves vizsgálat eredményei. Az alábbi táblázat a kérdőíves vizsgálat eredményeit tartalmazza, osztályokra tagolva, százalékarányban.

\section{1. táblázat}

A kérdőíves vizsgálat helyesírási hibaszázalékai

\begin{tabular}{|c|c|c|c|c|c|}
\hline & 1. feladat & 2. feladat & 3. feladat & 4. feladat & 5. feladat \\
\hline 5. A & $30 \%$ & $23 \%$ & $27 \%$ & $7 \%$ & $13 \%$ \\
\hline 5. B & $41 \%$ & $22 \%$ & $28 \%$ & $3 \%$ & $6 \%$ \\
\hline 9. A & $59 \%$ & $0 \%$ & $25 \%$ & $16 \%$ & $0 \%$ \\
\hline 9. B & $56 \%$ & $0 \%$ & $31 \%$ & $0 \%$ & $13 \%$ \\
\hline
\end{tabular}

2.4. A tollbamondások vizsgálata. A vizsgálat során a három évfolyam tanulóitól összesen 127 füzet állt a rendelkezésemre. Kutatásom során KISS JENŐ 1989-ben, a rábaközi Mihályiban végzett vizsgálatát vettem alapul. KISS a vizsgált hibákat a következő csoportokra osztotta (KISS 1999: 375): 1. a hiba forrása a tanuló nyelvjárásfüggősége; 2. a hiba forrása nem a tanuló nyelvjárási meghatározottsága. Kutatásom során a következő kategóriákat határoztam meg: 1. Nyelvjárási kiejtésfüggő helyesírási hibák; 2. Köznyelvi és nyelvjárási kiejtésfüggő helyesírási hibák; 3. Kiejtéstől független helyesírási hibák.

\subsubsection{A tollbamondások helyesírási hibaszázalékai}




\section{2. táblázat}

Az ötödik A és B osztály eredményeinek összegzése

\begin{tabular}{|l|c|c|}
\hline \multicolumn{1}{|c|}{ Nyelvjárási jelenség } & $\begin{array}{c}\text { A hiba gyakorisága } \\
\text { 5. A }\end{array}$ & $\begin{array}{c}\text { A hiba gyakorisága } \\
\text { 5. B }\end{array}$ \\
\hline A szótagzáró $l$ fonéma kiesése & $9 \%$ & $10 \%$ \\
\hline -ba/-be -ban/-ben helyett & $7 \%$ & $15 \%$ \\
\hline A szótagzáró $z$ fonéma kiesése & $4 \%$ & $14 \%$ \\
\hline $\begin{array}{l}\text { Köznyelvi és nyelvjárási kiejtésfüggő } \\
\text { hibák }\end{array}$ & $34 \%$ & $29 \%$ \\
\hline $\begin{array}{l}\text { Hosszú msh. köznyelvi rövid msh. } \\
\text { helyett vagy hiperkorrekció }\end{array}$ & $33 \%$ & $29 \%$ \\
\hline Rövid msh. köznyelvi hosszú helyett & $13 \%$ & $13 \%$ \\
\hline
\end{tabular}

\section{3. táblázat}

A kilencedik A és B osztály eredményeinek összegzése

\begin{tabular}{|l|c|c|}
\hline \multicolumn{1}{|c|}{ Nyelvjárási jelenség } & $\begin{array}{c}\text { A hiba gyakorisága } \\
\mathbf{9 . A}\end{array}$ & $\begin{array}{c}\text { A hiba gyakorisága } \\
\mathbf{9 . ~ B ~}\end{array}$ \\
\hline A szótagzáró $l$ fonéma kiesése & $11 \%$ & $9 \%$ \\
\hline -ba/-be -ban/-ben helyett & $23 \%$ & $22 \%$ \\
\hline A szótagzáró $z$ fonéma kiesése & $0 \%$ & $0 \%$ \\
\hline $\begin{array}{l}\text { Köznyelvi és nyelvjárási } \\
\text { kiejtésfüggó hibák }\end{array}$ & $27 \%$ & $20 \%$ \\
\hline $\begin{array}{l}\text { Hosszú msh. köznyelvi rövid msh. } \\
\text { helyett vagy hiperkorrekció }\end{array}$ & $33 \%$ & $42 \%$ \\
\hline $\begin{array}{l}\text { Rövid msh. köznyelvi hosszú } \\
\text { helyett }\end{array}$ & $6 \%$ & $7 \%$ \\
\hline
\end{tabular}

3. A kutatás eredményeinek összegzése. A vizsgálatot egy hipotézis megfogalmazásával indítottam. Feltételeztem, hogy a vizsgált ötödik és kilencedik osztályos tanulók helyesírása bizonyos jelenségek vonatkozásában nyelvjárási meghatározottságú. Hipotézisemet arra alapoztam, hogy miután összegyüjtöttem a tanulók dolgozatait, majd futólag átlapoztam azokat, az esetek többségében a nyelvjárási háttérrel összefüggésbe hozható hibatípusokat véltem fölfedezni. A kutatás első fázisában az ötödik osztályos tanulók dolgozatait vizsgáltam meg. Az ötödik osztályos tanulók esetében hipotézisem igazolódott: a vizsgált helyesírási hibák jelentős része a tanulók nyelvjárási hátterével hozható öszszefüggésbe. A kutatás második fázisában a kilencedik osztályos tanulók dolgozatainak vizsgálatával foglalkoztam. Feltételeztem, hogy mivel a kilencedik évfolyam az általános iskolai képzést záró évfolyam, a diákok írásbeli dolgozataiban csak elenyésző számban fordulnak elő a nyelvjárási háttérből adódó helyesírási hibák. Feltételezésem a kilencedik osztályos tanulók esetében is igazolódott. - A következőkben kísérletet teszek a kutatás során észlelt hibatípusok előfordulásának magyarázatára. 
3.1. Hosszú mássalhangzó használata köznyelvi rövid mássalhangzó helyett. A tanulók dolgozataiban leggyakrabban előforduló hibatípusról van szó. A hibatípus előfordulása véleményem szerint részben a hiperkorrekcióval hozható összefüggésbe. A hiperkorrekció (túlhelyesbítés) a nyelvi attitüdnek egy sajátos megnyilvánulási formája. KISS JENŐ meghatározása szerint hiperkorrekcióról akkor beszélünk, amikor „,helytelennek tartott, hibásnak érzett nyelvi formák kerülésének a szándéka, illetőleg tudatalatti mechanizmusa, tehát a stigmatizálódástól való félelem (...), túlhelyesbített, hiperkorrekt formákat eredményez" (KISS 1995: 147). A túlhelyesbítés jelensége a beszélt és írott nyelvben egyaránt előfordulhat. A szakirodalom a téves visszaütés, (téves) regresszió, hiperurbanizmus, hiperkorrekció, túlzott javitás, túlkompenzáció terminusokkal jelöli. A hiperkorrekció általában olyan helyzetekben jelentkezik, amikor a nyelvi rendszeren belül valamilyen bizonytalanság van (KISS 1995: 147). A hiperkorrekt helyesírási hibák összegzése során felkeltették az érdeklődésemet azok a hibatípusok, amikor a tanulók intervokális helyzetben köznyelvi rövid mássalhangzó helyett hosszú mássalhangzót jegyeztek le (elbeszéllö, pontossan). Annak érdekében, hogy kiderüljön, nyelvi bizonytalanság vagy a szóbeli nyelvhasználat írásbeli nyelvhasználatra való hatásáról van-e szó, újabb adatgyüjtési módszerre volt szükség. A felolvasási feladat esetében a diákok egyenként olvasták fel a feladatlapon található öt mondatot, amelyek az említett hibatípus feltérképezésére irányuló kifejezéseket tartalmaztak. Az ötödik A osztály húsz tanulója közül mindössze 2 diák akadt, aki a repülő és az elbeszélő kifejezésekben a köznyelvi rövid $l$ fonémát hosszan ejtette. Az ötödik B osztályban szintén két tanuló ejtette hosszan a köznyelvi rövid $l$ fonémát, azonban mindketten szinte azonnal kijavították az elhangzottakat, így ez az adat nem értékelhető, akár nyelvi botlásként is elkönyvelhető. A kilencedikes tanulóknál három esetben fordult elő, hogy köznyelvi rövid mássalhangzót a diák hosszan ejtett, viszont meg kell említenem, hogy az újraolvasás során már egyikük sem ejtette hosszan az adott kifejezést. Ezt az adatot nem tartom értékelhetőnek, mivel a diákok kijavították a hibát.

Fontos megjegyezni, hogy a felolvasási feladat esetében a tanulókra hatással lehetett az íráskép is, ezért tartottam indokoltnak a képről való meséltetés módszerének alkalmazását. Az ábrák kiválasztásánál azokra a fogalmakra koncentráltam, amelyek a tanulók dolgozataiban is szerepeltek. A vizsgálat eredményeinek összegzése egyértelmüen arról tanúskodik, hogy mindhárom évfolyam esetében a diákok a köznyelvi rövid mássalhangzókat nem csupán hosszan jegyzik le, hanem a szóbeli megnyilvánulásuk során is hosszan ejtik. Hosszú mássalhangzó használata köznyelvi rövid mássalhangzó helyett két okból kifolyólag is előfordulhat. Az egyik, hogy a tanuló az adott kifejezést a szóbeli megnyilvánulás során is hosszan ejti. Ebben az esetben a szóbeli és írásbeli nyelvhasználat szoros összefüggéséről beszélhetünk. A hibatípus előfordulásának másik oka a nyelvi bizonytalanságból fakadó túlhelyesbítés.

3.2. Köznyelvi és nyelvjárási kiejtésfüggő helyesírási hibák. Ebbe a csoportba azokat a hibatípusokat soroljuk, amelyeket a köznyelvben és a nyelvjárási formában is egyformán ejtünk (lesz, egy), valamint azokat a kifejezéseket, melyekben érvényesül valamilyen fonetikai törvény, esetünkben többnyire részleges hasonulás (azonban, különben). Ezekben az esetekben egyértelmű az összefüggés a szóbeli és az írásbeli nyelvhasználat között. Amennyiben a tanuló nem ismeri a helyesírás valamely alapelvét, előfordulhat, hogy az adott kifejezést olyan formában fogja lejegyezni, ahogy azt hallja. 
3.3. Rövid mássalhangzó jelének használata köznyelvi hosszú mássalhangzó jele helyett. A dolgozatokban magas számban fordult elő rövid mássalhangzó jelének használata köznyelvi hosszú mássalhangzó jele helyett (mondogaták, felmeni). A hibatípus előfordulásának egyik lehetséges okaként ismét a szóbeli és írásbeli nyelvhasználat öszszefüggését tartottam. A hipotézis megerösítésére szükséges volt a diákok körében végzett passzív megfigyelés, mely során a diákok között elvegyültem, hogy spontán beszédüket tanulmányozzam. Spontán beszéden a tanulók azon megnyilvánulásait értem, melyeket a tanítási órák közötti szünetekben, az egymással való kommunikáció során használnak. A spontán beszéd megfigyelése során nem találkoztam olyan esettel, hogy a tanuló a szóbeli megnyilatkozásában köznyelvi hosszú mássalhangzó helyett rövid mássalhangzót használna. Ebben az esetben tehát valószínünek tartom, hogy a tárgyalt hibatípus esetében kizárható a szóbeli és írásbeli nyelvhasználat összefüggése. A hibatípus előfordulásának gyakoriságát a tanuló nyelvi, illetve helyesírási bizonytalanságának tulajdonítom.

3.4. Az l fonéma kiesése a -ból/-böl, -ról/-röl ragok végéről. Az l fonéma kiesésének (elhagyásának) jelensége egyértelműen a szóbeli és írásbeli nyelvhasználat szoros összefüggését mutatja (osztálybó, beszédjérő). A gyermek először a beszédet sajátítja el, s csak később az írást. A tornaljai nyelvjárásban az $l$ fonémát nem mindig ejtik. Amennyiben a kisgyermek az adott kifejezést nyelvjárásias formában tanulja meg, az írás elsajátítása után is ilyen formában fogja lejegyezni. Az $l$ fonéma eltünése más nyelvjárásokban is előfordul. Az alábbi hibatípusok előfordulását szintén ezzel a magyarázattal indoklom.

3.5. A -ba/-be határozórag használata -ban/-ben helyett. A Hol? kérdésre felelő szavakban a -ban/-ben határozóragokat -ba/-be alakkal helyettesítették (koromba, barlangokba). Általános nyelvjárási jelenségként tartjuk számon.

3.6. A $z$ fonéma kiesése -hoz/-hez/-höz rag végén. A vizsgálat során néhány esetben előfordult a $z$ fonéma kiesése rag végén (felekezetéhe, megméréséhe). A jelenség más nyelvjárásokban is elöfordul.

3.7. Hangkivetés, valamint az -rt hangcsoport eltûnése rag végén. A tornaljai nyelvjárásban gyakori a hangkivetés, s erre a jelenségre a vizsgált dolgozatokban is volt néhány példa (majnem). Jellemző továbbá a szóvégi -rt lerövidülése vagy eltünése (azé). Kivételt képeznek bizonyos elhomályosult ragos alakok (mert). A tárgyalt jelenség más nyelvjárásokra szintén jellemző.

4. Kutatómunkám során arra törekedtem, hogy az adatok összegyüjtésével és a vizsgálati eredmények lehető legpontosabb interpretációjával olyan tanulmány szülessen, amely a gyakorlatban is jól felhasználható. Tornalja településről mind az általános, mind az alkalmazott nyelvjáráskutatás terén meglehetősen kevés adatunk van. Hasznosnak tartanám, ha a vizsgált térségben dolgozó tanárok folytatnák az ehhez hasonló kutatásokat, s a magyar nyelv és helyesírás tanítása során - a pozitív nyelvjárási tudat megerősítése mellett - az ily módon feltárt írásbeli hibatípusok kiküszöbölésére is kellő figyelmet fordítanának (vö. még: PÉNTEK 2002; BODA 2011; HANICZKO 2012).

Kulcsszók: palóc nyelvjárás, alkalmazott dialektológia, nyelvjárási háttér hatása a helyesírásra, helyesírás-tanítás, Tornalja. 


\section{Hivatkozott irodalom}

BALOGH LAJOS 2001. A nyelvjárási anyaggyüjtés. In: MDial. 157-174.

BODA ANNAMÁRIA 2011. A helyesírás tanítása nyelvjárási hátterü tanulók számára. Anyanyelv-pedagógia 2011/3. http://www.anyanyelv-pedagogia.hu/cikkek.php?id=333 (2016. 04. 21.)

HANICZKO ANNA 2012. A nyelvjárási háttér hatása a tornaljai alapiskolások helyesírására. In: PRESINSZKY KÁROLY - VARGOVÁ ZUZANA szerk., Cesty $k$ vede. Utak a tudományhoz. Konstantin Filozófus Egyetem Közép-európai Tanulmányok Kara, Nyitra, 33-42.

IMRE SAMU 1971. A mai magyar nyelvjárások rendszere. Akadémiai Kiadó, Budapest.

KISS JENŐ 1989. Egy nyelvszociológiai szempont a dialektológiában: az életkor. Magyar Nyelv 85: $40-47$.

KISS JeNŐ 1995. Társadalom és nyelvhasználat. Szociolingvisztikai alapfogalmak. Nemzeti Tankönyvkiadó, Budapest.

KISS JENÖ 1999. Az anyanyelvoktatás, a nyelvjárások és a nyelvjárási hátterủ iskolák. Magyar Nyelvör 123: 373-382.

KISS JENŐ szerk. 2001. Magyar dialektológia. Osiris Kiadó, Budapest.

KOZMÁCS ISTVÁN - VANČONÉ KREMMER ILDIKÓ szerk. 2010. Közös jövőnk a nyelv II. Nyelvtudomány és pedagógia. FSŠ, UKF, Nyitra.

MDial. = Magyar dialektológia . Szerk. KIsS JeNŐ. Osiris Kiadó, Budapest, 2003.

PÉNTEK JÁNOS 2002. A nyelvi környezet és a helyesírás. Magyar Nyelvőr 126: 257-262.

Pletl Rita 2010. Az anyanyelvoktatás helyzete Erdélyben. In: KOZMÁCS IsTVÁN - VANČONÉ KREMMER ILDIKÓ szerk. 2010. 105-115.

VANČONÉ KREMMER ILDIKÓ 2010. Attitüdök a szlovákiai magyar pedagógusok nyelvhasználatában. In: KOZMÁCS ISTVÁN - VANČONÉ KREMMER ILDIKÓ szerk. 2010. 213-220.

\section{The effect of dialect phenomena on the spelling habits of primary school children in Tornalja}

The present study is aimed at the exploration of the written language use of 11 to 15 -year-old schoolchildren living in Tornalja (Slovakia), a settlement of the Palóc dialect region. On the basis of school essays written by 11 -year-olds and 15 -year-olds, as well as in a questionnaire study, I tried to find out whether dialect has an effect on the pupils' writing habits (spelling proficiency) and if it does, to what extent. The paper gives a detailed analysis of the types of spelling mistakes that occurred, attempts to explain them, and draws the reader's attention to the practical applicability of other similar studies.

Keywords: Palóc dialect, applied dialectology, the effect of dialect background on spelling, the teaching of spelling, Tornalja (Slovakia).

HANICZKO ANNA 